\section{Dwaj ludzie z szafą $w$ perspektywie genologicznej}

„Trzeba znać się na przenośni, proszę państwa!”

ostatnia kwestia Przygody człowieka poczciwego

Franciszki i Stefana Themersonów, 1937
O Dwóch ludziach z szafq napisano już bardzo wiele. Generalnie biorąc, w studiach filmoznawczych poświęconych tej unikatowej etiudzie dominuje perspektywa anegdotyczna. Dotyczy ona głównie genezy jej nakręcenia (jak wiadomo, była to sfinansowana i wyprodukowana przez łódzką szkołę filmową praca studencka na międzynarodowy konkurs filmów eksperymentalnych ogłoszony z okazji Światowej Wystawy Expo 58 w Brukseli) oraz - opisanych przez samego autora - barwnych okoliczności realizacji latem 1957 roku w sceneriach Trójmiasta[1].

W dalszym planie - i raczej okazjonalnie - pojawiają się natomiast refleksje piszących o tym filmie odnoszące się do zagadnień jego niezwykle oryginalnej poetyki ( $\mathrm{z}$ wyłączeniem obiegowego w przypadku omawiania Dwóch ludzi z szafą wątku ich powinowactw z surrealizmem). A już całkiem rzadko mamy do czynienia $\mathrm{z}$ refleksją o charakterze genologicznym, zaś w jej ramach z próbami określenia i adekwatnego nazwania formuły gatunkowej, jaką posłużył się Roman Polański, kreując ekranową opowieść o swoich bohaterach. Nie znaczy to, że nikt z badaczy interpretujących głębszy sens jego etiudy wcześniej podobnego typu refleksji nie podjął. Warto jednak kontynuować rozważania na ten temat.

Intrygujące, że ilekroć na widnokręgu pojawia się kwestia gatunkowej przynależności Dwóch ludzi z szafą, tylekroć natychmiast zaczynają się kontrowersje jej dotyczące. Dla jednych - to typowa alegoria. Dla innych - wieloznaczna historia o wymiarze symbolicznym. Jeszcze inni są skłonni definiować gatunek owej nietypowej - wymykającej się schematom - studenckiej etiudy jako „film awangardowy”, omijając i uchylając w ten sposób (przynajmniej do pewnego stopnia) problematykę samego gatunku.

Dołączyć do tego należy - niejednokrotnie formułowaną przez badaczy twórczości Polańskiego - alternatywną interpretację genologiczną, w myśl której chodzi o groteskę filmową. Niekiedy także
Images

vol. XV/no. 24

Poznań 2014

ISSN 1731-450X

\section{Wprowadzenie}

\section{Wokół gatunku}

mieście, oprócz Polańskiego, parokrotnie publikowali również: Henryk Kluba i Andrzej Kostenko.
[1] R. Polański, Roman, przeł. K. i P. Szymanowscy, Polonia, Warszawa 1989, s. 114-117. Relacje z okresu zdjęć do Dwóch ludzi z szafą realizowanych w Trój- 
mamy do czynienia z kolejnym uściśleniem, za sprawą którego groteska zmienia się w makabreskę. Wreszcie zdarza się również, że - bez podejmowania trudu bliższego określenia podobnej charakterystyki - Dwaj ludzie z szafą bywają nazywani dość dowolnie „filmem poetyckim”. Bywa też, że etiudę określano „filmem eksperymentalnym”, co jest dalekie od terminologicznej precyzji[2], termin ten w najrozmaitszych swoich formach dotyczy bowiem jedynie sposobu wytworzenia przekazu - odmiennego od wypróbowanych standardów produkcyjnych profesjonalnej kinematografii - i z tego względu nie może być uważany za gatunek lub też odmianę gatunkową.

Wbrew pozorom takie dyskusje wokół terminologii nie są to wcale sprawy błahe ani marginalne $\mathrm{z}$ punktu widzenia interpretacji samego filmu. Każda $\mathrm{z}$ wymienionych opcji kieruje naszą uwagę na inny aspekt całości. Niektóre zdają się wzajemnie wykluczać, co - jak postaramy się w dalszym ciągu wykazać - jest wrażeniem pozornym. Należy - moim zdaniem - odrzucić koncepcję, iż w grę wchodzi w tym przypadku efektowna hybryda gatunkowa[3]. Etiuda Polańskiego wprawdzie łączy w sobie elementy kilku różnych gatunków filmowych, nie znaczy to jednak, iż z tego powodu ma być uznana za hybrydę gatunkową sensu stricto, nie występuje w niej bowiem podstawowa cecha hybrydy gatunkowej, jaką jest egzotyczna niespójność wykorzystanych w danym filmie elementów poszczególnych gatunków.

Wydaje się, że owo rozstrzelenie propozycji analityczno-interpretacyjnych dotyczących formuły gatunkowej Dwóch ludzi z szafa jest na tyle wymowne, symptomatyczne i intrygujące, że należy uważniej niż dotąd przyjrzeć się cechom konstrukcji tego utworu, zwłaszcza że jego format i miniaturowe rozmiary zaskakują zarówno nieoczekiwaną rozpiętością wachlarza gatunków, jak i pojemnością semantyczną kwestii, których - w sposób nader kunsztowny i przemyślny - użyto do jego zaprojektowania.

Fabularność versus afabularność
Zagadnienie fabularności bądź też afabularności historii, jaka została opowiedziana w Dwóch ludziach z szafą, należy do podstawowych pytań towarzyszących analizie konstrukcji tego filmu. Bieg zdarzeń ukazanych na ekranie na pierwszy rzut oka wydaje się wskazywać na udział standardowej dla opowieści fabularnych - konstrukcji przyczynowo-skutkowej. A jednak, gdy zastanowimy się nad sposobem powiązania z sobą poszczególnych epizodów, okaże się, że fabularność ukazanej akcji ma charakter wielce problematyczny. Przestrzeń znaczeniowa pomiędzy nimi okazuje się znacznie szersza niż - przewidywany i oczekiwany przez widza - układ logicznie związanych przyczyn i skutków.
[2] Jest znamienne, że z taką właśnie etykietką „filmu eksperymentalnego" Dwaj ludzie z szafa zostali niegdyś nakręceni i zaprezentowani w konkursie filmowym z okazji Expo 58. Określenie „film eksperymentalny" pojawiło się także w pierwszych polskich enuncjacjach prasowych z roku 1958.
[3] M. Hendrykowski, Hybryda gatunkowa, w: Leksykon gatunków filmowych, red. M. Hendrykowski, Studio Filmowe „Montevideo”, Poznań-Wrocław 2001, s. 80-83. 


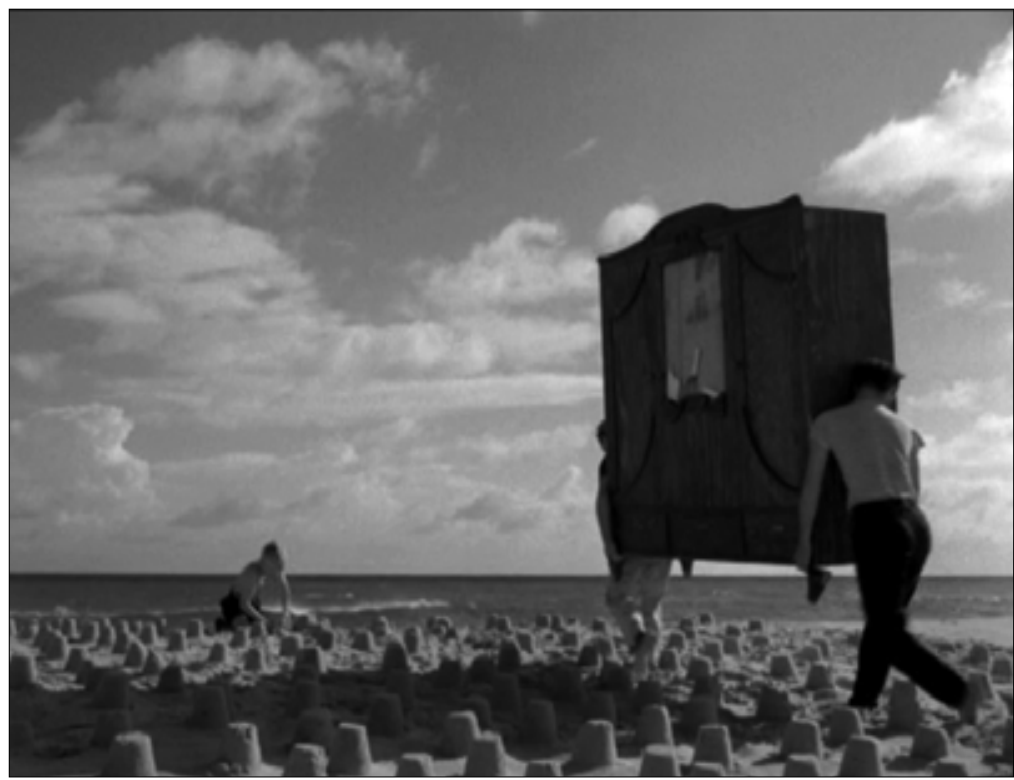

Już samo pojawienie się bohaterów wyłaniających się z morza z niesionym przez nich nieporęcznym rekwizytem ma charakter zaskakująco niedorzeczny i absurdalny, niczym egzystencja bohatera słynnego wiersza Leśmiana, w którego opisie padają słowa: „Pysk miał z żabia ślimaczy, że też taki żyć raczy”. Nie ma także logicznego związku między kolejno następującymi po sobie zdarzeniami z ich - niekiedy osobistym, a niekiedy zapośredniczonym poprzez doświadczenie osób trzecich - udziałem: próbą wejścia do tramwaju, spotkaniem z piękną dziewczyną przyglądającą się ptakowi uwięzionemu w klatce na sklepowej wystawie, zamordowaniem kota przez grupę chuliganów, pobiciem przez nich obu łazików, morderstwem nad potokiem itd. Nie chodzi tu bowiem o uporządkowaną, jednotorową fabułkę. Co więcej, układ ekranowych zdarzeń zakłada - celowo wydobywany od czasu do czasu przez filmowego narratora - brak spójnej logiki przyczynowo-skutkowej. Rzeczywistość, jaką oglądamy, jest tyleż nielogiczna, co nieludzka. Kiedy nasi bohaterowie zostają wyproszeni z jadłodajni w pensjonacie wczasowym, żegnają ich wyniosłe spojrzenia jedzących tam gości. Wszystkiemu winna jest ogromna szafa, którą daremnie usiłują wnieść do środka. Jej posiadacze natychmiast stają się kimś obcym: intruzami w lepszym towarzystwie. Owo „lepsze towarzystwo” nie ma jednak nic przeciwko temu, by przy obiedzie - pośród stołujących się - siedział w charakterze gościa potężny pies bernardyn.

Jeśli jednak nie łańcuch przyczynowo-skutkowy, to co w takim razie spaja poszczególne epizody? Czy chodzi tu tylko o dwóch łazików z szafą przemierzających nasz świat, czy może o pewien obraz tego świata, w którym nigdzie nie ma dla nich miejsca? Scena po scenie, nosiciele szafy przesuwają się przed oczami widza, przeżywając jedna po drugiej 
niemiłe przygody. Perypetii tych mogłoby być mniej lub więcej. W sensie fabularnym nie łączą się one na zasadzie wynikania, spaja je natomiast co innego, mianowicie odniesienie do ukazanego obrazu świata.

Odnosi się wrażenie, że każdy z luźno powiązanych z sobą epizodów stanowi rodzaj ilustracji prezentującej stan spraw, jakie na tym świecie okazują się być przykrą, a niekiedy groźną codziennością. Z tego względu kolejne epizody konstruuje Polański zawsze z tą samą myślą o konfliktowym charakterze rzeczywistości, którą poprzez nich, ale także niezależnie od nich, opisuje. Mamy tu do czynienia z ciągiem zdarzeń zainscenizowanych na zasadzie serii sytuacji ekranowych, z których każda - wychodząc od sensu dosłownego - realizuje ponadto pewien szerszy i bardziej rozległy obraz, w gruncie rzeczy przywodzący na myśl wielką metaforę.

W dalszych rozważaniach spróbujemy podążyć tym tropem, stawiając już na samym początku roboczą hipotezę, w myśl której konstrukcja Dwóch ludzi z szafą ma charakter paraboliczny.

Wokół definicji filmowej paraboli
Nasze rozważania nad kwestią parabolicznej konstrukcji etiudy Polańskiego zacznijmy od etymologii. Parabola jest pojęciem abstrakcyjnym wywodzącym się ze starożytnej geometrii. Greckie 'pará' oznacza 'ponad', 'poza czymś,' 'przez, 'obok,' 'przy'. Drugi człon złożenia odnosi się do 'czaszy'. Rzeczownik 'parabolể znaczy tyle, co 'porównanie’, przymiotnik 'parabolikós' = 'porównawczy'. W słowniku pojęciowym geometrii wykreślnej parabola oznacza linię krzywą, która skupia punkty znajdujące się w jednakowej odległości od punktu zwanego ogniskiem oraz danej linii prostej zwanej 'kierownicą'.

Pojęcie paraboli - wykorzystując je umownie w sensie metaforycznym - przeniósł na grunt refleksji teoretycznej nad poetyką

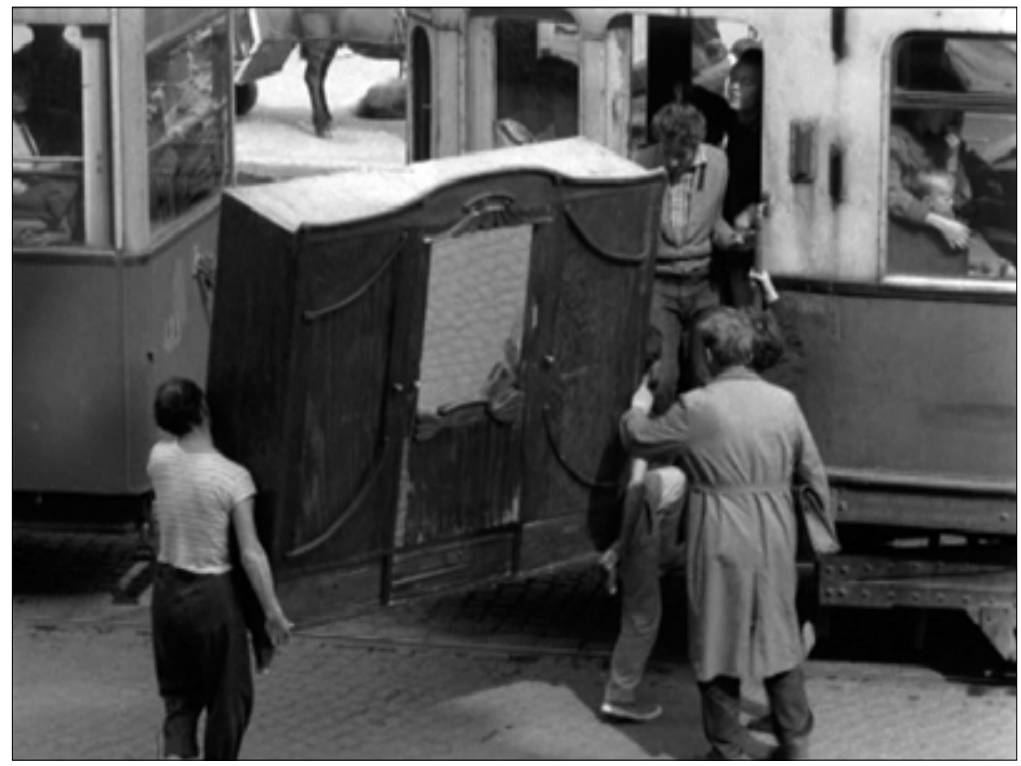


literatury Arystoteles. Parabola użyta przez niego w tym kontekście oznacza krótki utwór literacki, opowiadanie o charakterze alegorii, przypowiastkę o tematyce dydaktyczno-moralnej.

Od czasów Poetyki Arystotelesa nic się w tym względzie zasadniczo nie zmieniło. W definicji słownikowej sporządzonej przez znakomitego teoretyka literatury Janusza Sławińskiego dla potrzeb Słownika terminów literackich termin 'parabola' został opatrzony odsyłaczem do 'przypowieści'. Tę z kolei autora hasła zdefiniował następująco: „gatunek literatury moralistycznej; utwór narracyjny, w którym przedstawione postaci i zdarzenia nie są ważne ze względu na swe cechy jednostkowe, lecz jako przykłady uniwersalnych prawideł ludzkiej egzystencji, postaw wobec życia i kolei losu”. Badacz dodaje jeszcze, iż „świat przedstawiony przypowieści stanowi zbiór sytuacyjnych wykładników jakiejś ogólnej prawdy moralnej, filozoficznej czy religijnej”[4]. Warto odnieść powyższą definicję paraboli do analizy gatunkowej etiudy Polańskiego. Być może właśnie paraboliczność stanowi jej charakterystyczny wyróżnik gatunkowy - w ostatecznym rachunku właściwej temu filmowi konstrukcji nadający mu taką, a nie inną wymowę.

Parabola jako model kompozycyjny i zarazem gatunek utworu filmowego w kształcie wypracowanym przez twórcę Dwóch ludzi z szafa przywodzi na myśl synonimiczne względem niej określenia gatunkowe, takie jak: przypowieść, powiastka oraz moralitet. Do charakterystycznych wyznaczników tego gatunku, nie tylko w filmie, ale także w literaturze i sztukach widowiskowych, należy stała obecność roztrząsań dotyczących zagadnień Dobra i Zła (z immoralnością świata włącznie) oraz udział autorskiej refleksji nad egzystencją i losami człowieka.

Innym znamiennym elementem konstrukcji przedstawień parabolicznych jest wizerunek bohatera, Everymana, będącego alegorią człowieka jako istoty uniwersalnej. Spostrzeżenie to w odniesieniu do Dwóch ludzi z szafa zawdzięczam analizie kilkudziesięciu kadrów scenorysu, jaki sporządził reżyser przed przystąpieniem do realizacji zdjęć. Na rysunkach tych widać znaczny stopień schematyzacji przedstawień, połączonej z usuwaniem $\mathrm{z}$ nich wszelkich rzeczy mających jakikolwiek indywidualny wyraz. Jedna $\mathrm{w}$ drugą są to modelowe sylwetki postaci uchwyconych w ekranowych sytuacjach. W efekcie opisanego zabiegu uniwersalizacji powstaje zamierzone przez twórcę wrażenie egzemplarycznej ilustratywności ukazanego obrazu świata.

Z perspektywy blisko ćwierćwiecza, które upłynęło od likwidacji instytucjonalnej cenzury w Polsce, przyzwyczajeni do swobody wypowiedzi, jaką się od tak dawna cieszymy, coraz częściej zapominamy

Parabola jako język ezopowy PRL o istnieniu ezopowego języka literatury, filmu i innych sztuk uprawianych przez dziesiątki lat w PRL. Pisarze i filmowcy wytworzyli specyficzny język podtekstów i aluzji, angażując do tego celu środki wyrazu, 


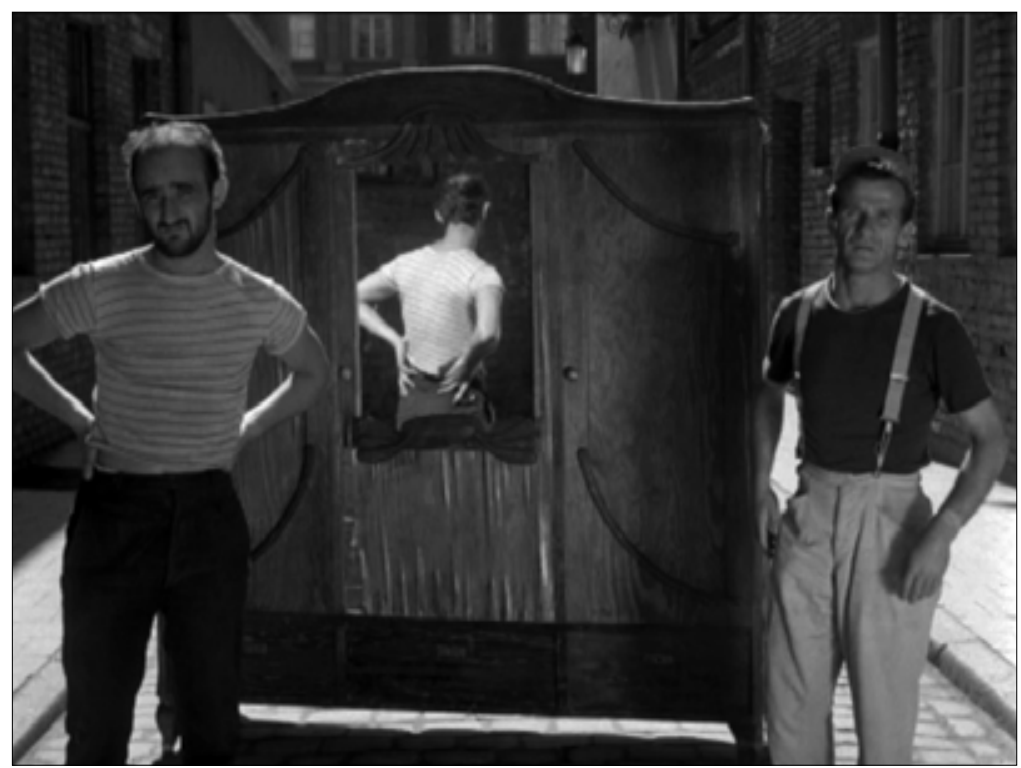

konwencje, chwyty, a zwłaszcza pewne gatunki, do których należały: alegoria, powieść z kluczem, parabola, powiastka filozoficzna i inne.

Krytyka rzeczywistości wyrażana $\mathrm{w}$ formie całkowicie bezpośredniej i otwartej była wówczas prawie niemożliwa. Zamiast niej funkcjonował w sztuce polskiej rozbudowany system różnego rodzaju podtekstów, aluzyjnych przenośni, symboli i alegorii, którego kwintesencję artystyczną odnaleźć można między innymi w obrazie Bronisława Wojciecha Linkego Autobus (1955-1960) [5], animowanym filmie Waleriana Borowczyka i Jana Lenicy Był sobie raz (1957) oraz w powieściach Jerzego Andrzejewskiego: Ciemności kryją ziemię (1957) i Bramy raju (1960).

W Dwóch ludziach z szafą i w innych utworach tego typu nie chodzi zatem o samą fabułę, która jest mało istotna i może być wręcz szczątkowa. Nie chodzi też o kostium i ukazane realia, bo te niosą z sobą sens umowny. Chodzi o domyślne (czytaj: paraboliczne) znaczenie serii ukazanych sytuacji, którym nadano w dziele przenośny sens. Artyści uczynili z cenzuralnych ograniczeń i zakazów pierwszorzędnie ważny motyw własnej sztuki. Powiedzieć coś nie wprost, wykreować wyszukaną aluzję, wyrazić rzecz omownie i metaforycznie, przenieść ją w inny, niedosłowny wymiar - stało się w sztuce PRL wysoko cenioną umiejętnością.

Studencka etiuda Romana Polańskiego sięga do tego samego arsenału środków artystycznej ekspresji. Jej autor odwołuje się do sztafażu współczesnych realiów polskiego miasta lat pięćdziesiątych, a jednocześnie wprowadza w jego rzeczywistość dwóch bohaterów 
rodem $z$ innego świata, ani przez moment nie zapominając, że dwoma komplementarnymi żywiołami całej opowieści są zarówno realność, jak i fikcja poetycka. To charakterystyczne połączenie i wzajemne przenikanie jednego z drugim staje się wymowną parabolą otaczającej nas rzeczywistości.

Dwaj ludzie z szafa nie są ciągiem barwnych przygód dwóch obieżyświatów. Kolejne sytuacje życiowe, w jakich oglądamy ich na ekranie, liczą się jedynie o tyle, o ile mają charakter egzemplaryczny (łac. exemplum = przykład, wzór), a każda $\mathrm{z}$ nich pełni rolę egzemplifikacji (łac. exemplificatio = objaśnienie, udowadnianie czegoś za pośrednictwem przykładów, bycie przykładem czegoś). Poza kompozycyjną ramą wynurzenia i ponownego zanurzenia się bohaterów w morzu nie ma w tej etiudzie zdarzeń wyróżnionych. Wszystkie - i na tym polega geometria paraboli literackiej, filmowej i w ogóle artystycznej - odnoszą się w jednakowej mierze do ogniska opowieści, którą oglądamy. Owo znaczeniowe ognisko staje się zadaniem dla jej adresata.

Wydaje się, iż w tym momencie rozważań znaleźliśmy się nieco bliżej odpowiedzi na pytanie o właściwy gatunek etiudy Polańskiego. Podstawę jej charakterystyki gatunkowej stanowi przypowieść, czy - jak kto woli - miniaturowych rozmiarów powiastka filozoficzna. Paraboliczna struktura Dwóch ludzi z szafa niesie z sobą szczególny sposób związania i połączenia w jedno formy i treści tego utworu. Warto w tym miejscu wsłuchać się w wypowiedź samego Romana Polańskiego otwierającą jego autobiograficzną książkę napisaną i opublikowaną trzydzieści lat temu:

Jak daleko sięgam pamięcią, granica między fantazją a rzeczywistością była u mnie zawsze beznadziejnie zamazana. Potrzebowałem niemal całego życia, by zrozumieć, iż właśnie w tym tkwi klucz do istoty mojej egzystencji[6].

Zacytowane powyżej wyznanie wybitnego artysty filmowego można potraktować jako sui generis deklarację twórczą. W takim przypadku będzie ona dotyczyć czegoś więcej niż tylko specyficznego rodzaju percepcyjnej i egzystencjalnej relacji między jednostką a światem. W o wiele większym stopniu zawarta w niej wskazówka odnosi się - jako przenikliwy autokomentarz twórcy - do charakterystyki sposobu widzenia i ukazywania rzeczywistości, z jaką mamy do czynienia zarówno w Dwóch ludziach z szafą, jak i praktycznie we wszystkich filmach nakręconych przez Polańskiego: od Roweru, Morderstwa, Uśmiechu zębicznego i Rozbijemy zabawę, poprzez Dwóch ludzi z szafa, Gdy spadają anioły, Ssaki i Nóż w wodzie, dalej Wstręt, Dziecko Rosemary, Tragedię Makbeta, Chinatown i Lokatora, aż do dzieł najnowszych: Olivera Twista, Autora widmo, Rzezi i Kobiety w futrze.

Ekranowa rzeczywistość, o której tu mowa, prezentuje - parafrazując słynną formułę wolteriańską - świat nienajlepszy z możliwych. Zwykłemu człowiekowi żyje się w niej ciężko, niezwykłemu - jeszcze

[6] R. Polański, op. cit., s. 9.

\section{Dwaj ludzie z szafa jako struktura paraboliczna}




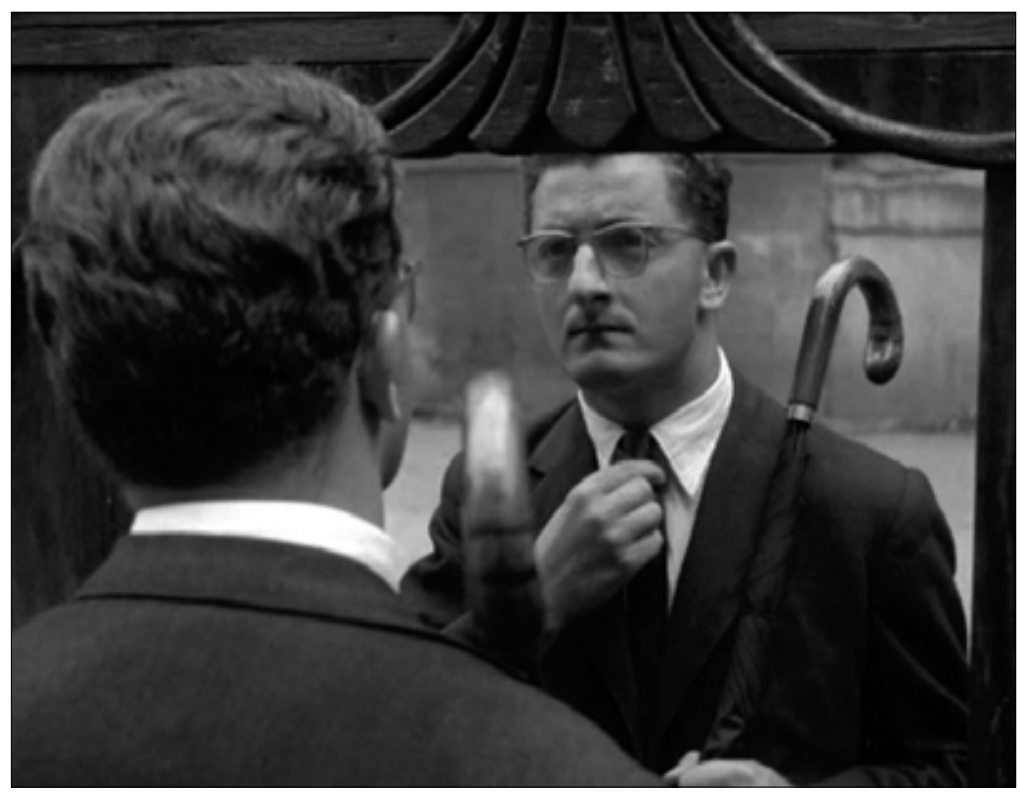

gorzej. Nie chodzi przy tym o konflikt człowieka z przyrodą, o istnienie groźnych kataklizmów i katastrof unicestwiających w mgnieniu oka ludzkie życie. Chodzi o rzeczywistość społeczną, a w niej o - nieredukowalną i niemożliwą do usunięcia - stałą obecność wrogości, nietolerancji, agresji i przemocy. O ile świat natury bywa piękny (tak go w pierwszej scenie filmu ukazano), o tyle świat międzyludzki okazuje się nieznośnie wprost obcy i wrogi.

W swoich filmach Polański nie jest moralizatorem w rozumieniu głosiciela i dawcy morałów. Nie znaczy to jednak bynajmniej, iż nie porusza w nich kwestii Dobra i Zła, że nie dostrzega ciemnych stron życia i natury ludzkiej. Owszem, nie tylko dostrzega, ale też nieustannie porusza i eksponuje tego rodzaju tematykę. Pytanie tylko: z jakich pozycji światopoglądowych to czyni? Obca jest mu przecież wszelka postawa religijna. Wręcz przeciwnie, zachowuje sceptyczną niewiarę i bezwzględną trzeźwość osądu. W swoim widzeniu i pojmowaniu świata zbliża się tym samym do poglądów filozoficznych francuskich pisarzy racjonalistów (zwłaszcza Denisa Diderota i Voltaire’a) oraz brytyjskich pisarzy i filozofów liberalnych (Jonathana Swifta, Henry’ego Feldinga, Daniela Defoe, empiryzmu Johna Locke'a, sensualizmu Davida Hume'a).

Dotykamy w tym miejscu kwestii podstawowej. Czy Dwaj ludzie z szafą są - ze względu na swoją charakterystykę gatunkową - dziełem absolutnie unikatowym na tle ówczesnego kina polskiego i światowego? Czy też, przeciwnie, okazują się utworem typowym dla tendencji obecnych w sztuce filmowej tamtego okresu? Odpowiedź na oba te pytania nie będzie ani prosta, ani też jednoznaczna. Zależy od tego, jak rozumiemy „unikatowość” i „typowość”. Jeśli wyraz unikatowość ma być synonimem „wyjątkowości” (zwłaszcza wyjątkowości absolutnej) wówczas etiuda Polańskiego odkrywa bogactwo swoich kontekstów 
w postaci sieci intertekstualnych związków z wieloma innymi filmami, do których się w ten czy inny sposób odnosi. Nie jest zatem absolutnie unikatowa.

Jeśli natomiast „typowość” będziemy pojmować jako standardowość w stosunku do formuły kina danego miejsca i czasu, Dwaj ludzie z szafą okażą się dalecy, a nawet bardzo dalecy od ówczesnego paradygmatu panującego w głównym nurcie rodzimej kinematografii. Ich twórca uczynił bowiem wiele, aby się z tego paradygmatu wyłamać: powołując do istnienia na ekranie rzeczywistość nietypową, umowną i zaskakująco odmienną. Groteskowość świata, jaki wykreował, nie jest w żadnym razie stylistyczną przyprawą ani sztucznie wykreowanym dodatkiem do jego charakterystyki. Zgodnie z poręcznym sformułowaniem Jeana Onimusa - staje się ona w jego filmie „doświadczeniem świadomości” [7].

Konstrukcja etiudy Dwaj ludzie z szafa opiera się na finezyjnie zaprojektowanym modelu filmowej paraboli. Należy jednak zastrzec, iż obecność struktury parabolicznej stanowi dominantę gatunkową tego utworu, nie zaś jedyny wyróżnik właściwego mu gatunku. Oprócz paraboli - a właściwie w ścisłym powiązaniu z nią - odnajdujemy również elementy i ślady obecności szeregu innych gatunków filmowych. Należą do nich: czarna komedia, tragikomedia, burleska slapstickowa, studium obyczajowe, dreszczowiec, dramat absurdu, groteska i makabreska.

Nie chodzi tu jednak o samo pojawienie się śladów tych gatunków czy też okazjonalną obecność pewnej liczby odmian gatunkowych. Wywołując poszczególne $\mathrm{z}$ nich i wpisując je w strukturę ekranowej przypowieści o dwóch takich, co nosili szafę, scenarzysta i reżyser precyzyjnie wyznaczał miejsce i funkcję każdemu z wybranych elementów. Ich organiczne połączenie w spójną całość wyższego rzędu stało się możliwe dzięki wspólnemu mianownikowi, jakim jest poetycki wymiar etiudy Polańskiego, w której zaprezentowana rzeczywistość spotyka się i na każdym kroku przenika $\mathrm{z}$ fantazją filmowca-artysty.

Dwaj ludzie z szafą należą do filmów o wysokim współczynniku wieloznaczności: stale otwartych na kolejne odczytania i interpretacje. Całość opowiadanej historii została tutaj konsekwentnie ukazana i utrzymana w formie refleksyjnej przypowieści o losie ludzkim i sytuacji człowieka na świecie. Po trwającej zaledwie krótką beztroską chwilę, pogodnej uwerturze stajemy się świadkami narastającego dramatu egzystencjalnego połączonego $\mathrm{z}$ tragikomedią i dramatem absurdu.

Bohaterowie przechodzą od sytuacji do sytuacji, nieustannie zmagając się przy tym z obojętnością, brakiem akceptacji, a często również z wrogością. Poszukując dla siebie azylu oraz miejsca do życia,

[7] J. Onimus, Groteskowość jako doświadczenie świadomości, przeł. K. Falicka, „Pamiętnik Literacki” 1979, z. 4, s. 319-327; zob. także: W. Kayser, Próba określenia

\section{Konkluzja} istoty groteskowości, przeł. R. Handke, „Pamiętnik
Literacki” 1979, z. 4, s. 271-28o. 
odkrywają, iż nikt na tym świecie ich nie kocha, nie lubi i nie akceptuje. Na swój sposób wyjątkowi - zasadniczo i rzec by można nieredukowalnie (szafa!) - różnią się od innych swymi dążeniami oraz tym, jacy są, i to czyni ich niemożliwymi do zaakceptowania przez otoczenie. Jedynym rozwiązaniem okazuje się w tej sytuacji powrót i rozpłynięcie się w alternatywnej rzeczywistości, do której należą.

Ważne przy tym, że wracają do własnego świata z szafą. Wprawdzie szafa ma stłuczone lustro, ale nadal z poświęceniem ją noszą. Czym ona jest w ich życiu - nie wiemy na pewno, ale możemy się domyślać. Dosłownie i w przenośni jest czymś nieodzownym i stałym: ciężarem, od którego - mimo wszelkich szykan i przeszkód - nie chcą się uwolnić. Dwaj ludzie z szafą, mimo swych niepozornych rozmiarów, są w pełnym tego słowa znaczeniu utworem wielowymiarowym. Jak przystało na dzieło sztuki, oznacza to, iż właściwa im forma i treść nie podlega i wymyka się ujednoznacznieniu: nie daje się sprowadzić do jednego prostego komunikatu.

Wyposażona w elementy szeregu innych gatunków, formuła gatunkowa paraboli, jaką posłużył się Roman Polański w swojej etiudzie, okazała się w ostatecznym efekcie niezmiernie funkcjonalna w stosunku do poruszonego tematu, doskonale służąc jego pogłębieniu i wyprowadzeniu na głębsze wody sztuki filmowej z prawdziwego zdarzenia.

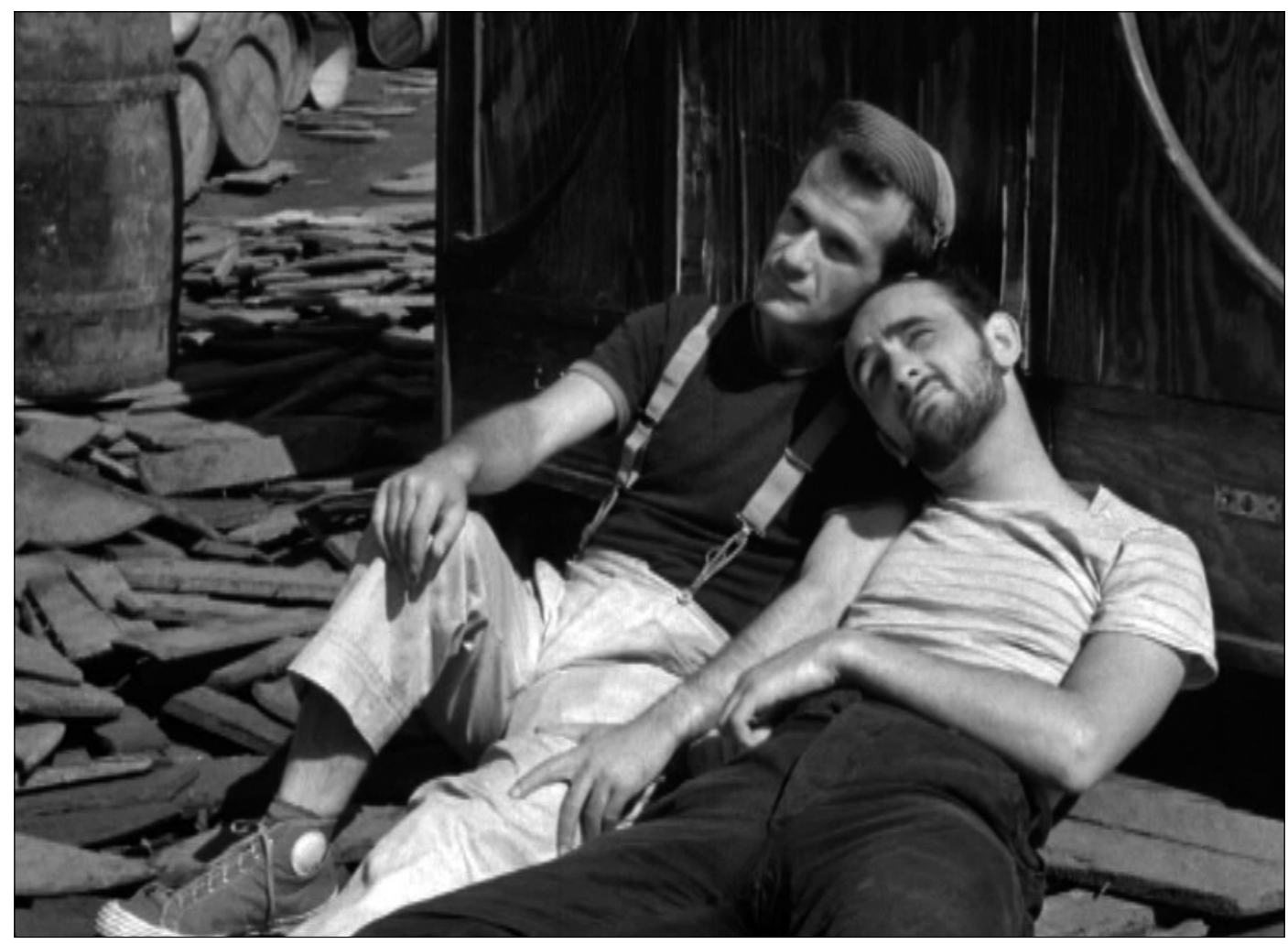

